\title{
A shift from peasant to intellectual-led political opposition in Tigray during the imperial regime (up to 1974)
}

\author{
Atsbha Gebreigziabher Asmelash \\ History and Heritage Management, College of Social Science and Humanities Debre Markos University, Ethiopia.
} Received 24 April 2014: Accepted 6 August, 2014;

\begin{abstract}
This paper examines how the educated people of Tigray took over the illiterate ones to fight against the imperial government. Local songs, poems and sayings used against Emperor Haileslasie are discussed. Following the liberation of Ethiopia from the Italian occupation in 1941, Emperor Haileslasie introduced a number of reforms, many of which were rejected by the people of Ethiopia. The imperial government used different measures including force to implement its policies. This created resentment in the people over whom repressive actions were undertaken. What happened in Tigray in 1942/43 is a good example. The Qedamay (First) Woyane Rebellion of 1942/43 broke out due to high taxation, maladministration, corruption, political feud etc. Although the rebellion failed because British Royal Arms intervened, the people did not remain submissive to the regime. A number of Tegaru University students from different Awrajas of Tigray joined Hailslasie I University at different times. The university served as an academic and political school where they agreed on how to save their communities from miserable lives. They formed an organization called Tigrean University Students Association (TUSA) that served them as an umbrella and binding pot. Members and supporters of this association were ready to pay any sacrifices for the betterment of their people. They made the society fight against the feudal regime and did everything to solve the problem of their people. With time, TUSA supporters increased. The association was renamed MAGEBT, then TNO and finally TPLF. Many Tegaru University students paid with their golden lives, time and properties in their struggle against the feudal regime. Finally, they successfully toppled the imperial regime. However, their struggle continued after the end of the imperial regime. Due to the absence of well organized civil government, another oppressive government, the Derg, assumed power.
\end{abstract}

Key words: First Woyane, TUSA, MAGEBT, TNO, university students, political opposition.

\section{INTRODUCTION}

The post-liberation political situation in Tigray

Due to the political ideology of the imperial regime, many parts of Ethiopia were not given the right to self governance or self administration. The centralization policy of Emperor Haileslasie did not allow this to happen. For this

E-mail: a tsbita 12@gmail.com, atsbhagegzia bher@ya hoo.com. Tel: +251911183199, +251920658925.

Author a gree that this article rema in permanently open access under the terms of the Creative Commons Attribution License 4.0 Intemational Lic ense 
reason, many on-Tigrean government officials came to Tigray Province. As many non-Tigrean government officials were assigned to administer many parts of Tigray, the people of the province developed hatred attitude towards their governors. The people of Tigray expressed their anger towards the imperial regime through the use of different sayings.

The following was one of the popular ones: "UmY kù $1 / 4$ ùlÖ "ê $\div Y N \mu$ ì TG\%oY YPIÖ" which literally means "Oh it is hardly possible to administer Tigray from Shoa". Their anger did not get a timely response from the officials. They lacked a patronage for their hardships and urgent requests. As time went by, the people of the province began to realize that their readiness to pay any form of sacrifice was the most important option. As a result, one informant, Memhir Mamo Teklehaimanot, expressed the determination of Tegaru as "GF>p MlêR $z Y<X L$ HZbp", meaning "people who are not submissive to an oppressive rule."1

It is obvious that the nature of relationship between the people of Tigray and the imperial regime under Emperor Haileslasie since the outbreak of Qadamy (First) Woyane Rebellion of 1942/43 was full of distrust. It is stated that although the Qedamay Weyane failed, sources uncover, it became a symbol of constant desire for the post Qedamay Weyane armed struggle against the imperial regime. In the long run, the uprising was far from unsuccessful. The Qedamay Weyane rebellion was not totally quelled. Rather, its challenge to the imperial regime continued in a different fashion and under different leadership in which the intellectuals replaced the leading role of the nobles and bandits. The coercive measures undertook against the people of Enderta Awraja both during and after the most formidable revolt of 1943 , particularly the British Royal Air Force bombardment of Meqelle on behalf of the Emperor remained unforgettable in the minds of Tegaru (Atsbha, 2012). ${ }^{2}$

Due to this reason, many people of Tigray sang "wR1/4p m\{T $\div \mathrm{NB}$ ttRxpú IYnY XMbR LbY ì iffú", meaning "As time went by, my eye slept but not my heart." As this song sung by sheep and cattle herders in the rural area, a considerable number of government officials realized that what the herders sang was the feeling of the masses. Thus, they began to supervise the daily songs of sheep or cattle herders. Because, it was considered as a short mechanism of assessing what the mass population felt. To this end, government officials were ordered to investigate what the herders sang every day: " $\mathrm{Xr}^{3} / 4{ }^{2} \hat{E} \quad M N$ zfn?" which literally means "what herders sing today?"3

According to oral and written sources, the people of Tigray gave due attention to the contribution of education to the development of a certain country or society. This can be seen from one of their popular saying, "H, $++\omega$ क $\angle$. h, person is nominal as what unsharpened stone mill is not functional." However, their academic demand was not met until the end of the Derg Regime.

According to Doctor Solomon Enquai's interview which was made with Woyeen Magazine on May 2010, "unlike the last generation, this generation is lucky enough." As to him, during the imperial period, there were only few primary and secondary schools with no college and university in Tigray. Following the return of Emperor Haileslasie from exile, most of the peoples of Ethiopia had not sympathetic attitude towards the imperial regime.

The people of Tigray were not exceptional and this was not without reasons. Since the reign of Emperor Menilik II up to the imperial rule of Emperor Haileslasie, there was firm belief among Shoan rulers of Tigray, that is "3\% 2 c.e

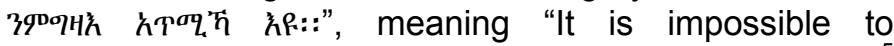
administer Tigray unless the province is kept hungry." 5 One of informant, Memhir Mamo Teklehaimanot shares this idea. He states it as follows: "KTgZX XNt $\div \mathrm{YN} \mu \mathrm{HZbp}$ TG\%oY $x_{\rightarrow}$ a $1 / 4 Z$ ", meaning "If you want to govern the people of Tigray keep the hungry." The following proverb shows how the people of Tigray was denied due respect among its feudal rulers: "XGzp"BÿR zfN spÃMéW TGÊ ÃGÆEL", meaning "The God feeds the people of Tigray as $\mathrm{He}$ [God] wants a person to sing for him." There was another way how the identity of the people of Tigray was wounded. It is enough to see the following saying, "TGE sp-GB g\#¥y s!RbW êYêy", meaning "Tigraway has no constant behavior: he sings and cries when he eats too much and feels hungry respectively." ${ }^{\prime 6}$

As mentioned above, immediately after the liberation of Ethiopia from the Italian occupation in 1941, there were about thirty nine (39) schools in Tigray Province. However, what happened in Tigray some months after the liberation of the country highly dissatisfied the people of the province. Because, through the order of Akaleworq Habtewold, the then Ministry of Education, all but three of the schools in Tigray were closed. The schools in Meqele, Adigrat and Adwa were believed to have been enough for no less than three million people of Tigray and another school was left from closure in Axum for religious education purpose.

The government's measure was not accepted by the people of Tigray without opposition and serious questions why such action was undertaken against a people who paid a number of sacrifice fighting against the Italian aggressors in the absence of the emperor. The government's response to their question was proved to be illogical for the fact that the people of the province were told that such measure was the result of their failure to pay enough amounts of taxes that would help the government to open many schools in the province. It was not due to their failure to pay high rate of taxes that their right to get adequate education was deprived. Because, other parts of Ethiopia, including Asmara and Addis Ababa, had many primary and secondary schools were 
opened, without paying special taxes. ${ }^{7}$

The complaints of the people of Tigray were not only confined to an opposition in the province but also extended to the extent of sending delegates to Addis Ababa to present their appeal to the emperor to reconsider their question. For instance, delegates of the people of Maichew went to Addis Ababa and asked the emperor " meaning "What wrong we did that our school is closed? Oh our children to be ignorant!" The emperor's response

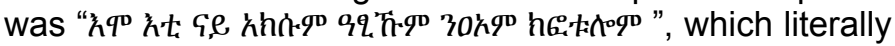
means "Open their school at the expense of the school at Axum."

What is impressive here to note is that the delegates sent from Maichew were not simple enough to be deceived by the decision of the emperor because, they were aware of the impact of such decision on the unity of the people of Tigray. For this reason, they replied "3hG

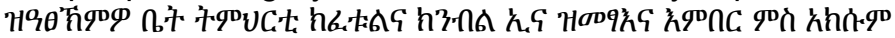

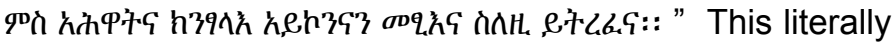
means "We came here to request you to reopen our closed school but not at the expense of our friends, Axum, with whom we did not like to quarrel. So, we withdrew our question." 8

\section{Campus life and politics in Haileslasie I University}

Even though they were few in number, Aregawi Berhe revealed that Tegaru secondary schools students of Nigiste Saba, Agazi and Atse Yohannis managed to complete their secondary level education with better courage. After they completed their secondary school education, some Tegaru students joined Haileslasie I University (HIU) where the political atmosphere, to some extent, was conducive to students articulating their grievances and coming together to form associations but not without cost. It was part and parcel of the campus life of many Tegaru students to participate actively in a political movement calling for change both at national and provincial level. For this reason, Tegaru university students played a pivotal role in the uncompromised struggle against the old regime under Emperor Haileslasie. HIU served as a meeting spot for politically minded Tegaru teachers and students from all awrajas of Tigray to meet together and to discuss on issues concerning the province as a whole. Some informants shared this idea. ${ }^{9}$

As can be understood both from oral and written sources, Tegaru higher institution students discussed the miserable life and the oppressive system that the majority of their community from which they came had to endure on the one hand and the luxury life style the ruling class were enjoying at the expense of the poor on the other hand. ${ }^{10}$

Land degradation, recurring famines, massive un- employment, political alienation, cultural domination and various aspects of social problems of the people of Tigray and their solutions were some of the major issues which were the major points of discussion among Tegaru university students. They managed to compare the level of the problems in Tigray with those in other corners of Ethiopia and they firmly believed that the situation in Tigray was by far the worst. ${ }^{11}$

John Young, in his article entitled "The Tigray People's Liberation Front" shares the above discussed idea. He expressed extent to which Tigrigna speaking university students in general and Tegaru in particular were political conscious. His article reads:

While Oromos and others more recently incorporated into the Ethiopian empire suffered the greatest oppression under the imperial regime, it was the Tigrinya speakers of Eritrea and Tigray were the most ethnically conscious: Tigrayans, who inhabited the heartland of the historic Ethiopian state, were especially resentful of their subordination to an Ahmara-dominated state, and Tigrayan students increasingly embraced the view that the best approach would be to engage in a national liberation struggle. Their deliberations led to the formation of the Tigray National Organization (TNO) which served as a link between militants in the university and their supporters in the towns, who were largely high school students and teachers, until the TPLF took form (Young, 1998). ${ }^{12}$

The imperial government left Tigray culturally dominated, economically poor and politically instable. The people's rights to speak and write using their mother tongue language to assemble and oppose were banned. Land in the province remained an income-generating asset of very few nobles and the masses were landless peasants. Any tendency of opposition against the old regime was met with military action and heavily taxing the people as a means to intimidate them not to once again oppose the imperial government. It was during this moment that intellectuals and students played a pivotal historical role in shaping the form of struggle the people must follow in order to achieve their freedom. The former put the corner stone of armed struggle among the people of Tigray. They raised many burning issues that had popular acceptance among the people of the province (Hiwehat, 1989). ${ }^{13}$

Many Tegaru University students were playing a vital rule in the pan-Ethiopian student movement against the feudal regime. What is necessary to note here, according to Aregawi Berhe, who was among the most activist Tegaru students and produced very rich account on the issue under discussion, is that the Tegaru university students were not aiming at restoring Tegaru's hegemony, as what "Some naïve politicians had presented it." Instead, they were patrons of the struggle against the 
imperial regime. In other words, Tegaru students of Haileslasie I University were comrades in struggle with revolutionary students including Wallillegn Meknonen, who was a Wolo-Amhara, fighting against the old regime. $^{14}$

Arkebe Equbay, interviewed by Weyeen Magazine in

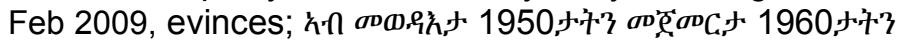

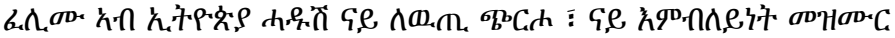

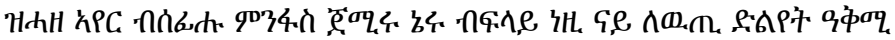

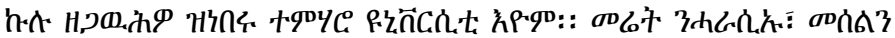

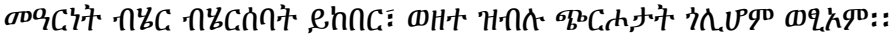

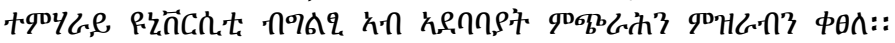

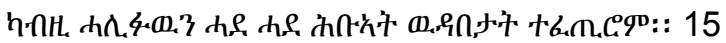

Since the late 1950s and early 1960s E.C., there was slogan advocating change and songs calling rebellion were dispatched in Ethiopia particularly by the university students. Several slogans including land to the tiller, respect the right of nations and nationalities and the like were commonly used. University students began to speak and read slogans openly in stages. In addition to this, few clandestine cells emerged.

In the late 1960s, when the pan-Ethiopian student movement was growing in scope, Tegaru students of HIU were very influential in every aspects of the University Students Union of Addis Ababa (USUAA). Gidey Gebre Wahd, Sibhatu Wubneh, Amare Tesfu, Tesfay Teklu, Mitiku Ashebir, Abebe Tesema, Atsbha Hailemariam, Gebrekidan Desta, Rezene Kidane, Tilahun Gizaw and Melese Tekle were some among the earlier prominent activists Tegaru University students. ${ }^{16}$

After their political consciousness became very strong, the need to have frequent meeting among the students themselves and between them and other section of the society highly increased. Particularly, during the vacation period, university and secondary school students as well as high school teachers had got good opportunities to meet together so as to discuss the oppressive nature of the feudal regime under Emperor Haileslasie and the reach on an agreement on how to end it. For instance, Tesfay Tekle, Rezene Kidane and Mituku Ashebir were some among the activist university students who highly shaped the student movement in Meqele Town. Tesfahunegn Asayehegn, Gebremedhin Kassa and Endiyaw Abera were some examples of high school teacher in Atse Yohannis Secondary School who strongly cooperated with the aforementioned university students in agitating mass based opposition in Tigray against the imperial regime. ${ }^{17}$

According to archival sources, the aforementioned students and teachers opposed the political and cultural domination of the imperial government over the people of Tigray. On 23 August 1969, these participants of the student strike in the town were reported to have moved from bar to bar, night club to night club and they were calling every bar and night club owners to use Tigrigna but not Amharic music. It is also stated that instead of Amharic music, they frequently encouraged the use of English music mainly "Long Live for youth".

Even though the activities of the students in Meqele Town were a great challenge to the then government, the latter undertook half-hearted measures up on the former. As can be seen from some archival materials, the reason why no strong action was taken up on the university students in Meqele was stated as follows: " $\mathrm{h} h \mathrm{H}, \mathrm{v}$ i 9 年

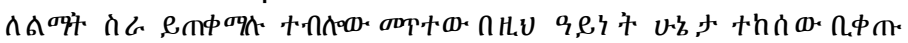

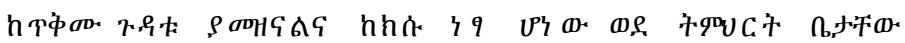

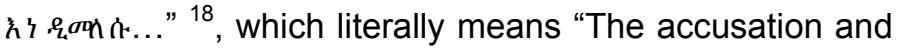
punishment of those people [university students], who are expected to share their contribution to the development program, due to their involvement in political activities has more disadvantages than its merits. Hence, it is better to return them to their study [university]."

\section{The Establishment of Tigrean University Students' Association (TUSA)}

As the pan-Ethiopian student movement became very strong, many student leaders were arrested among whom Brhane Mesqel Reda, Melese Tekel and Wallillegn Mekonen were cases in point and even these arrested were released due to frequent student demonstration in demand of getting release the arrested ones (Mulugéta, 2010). ${ }^{19}$

After the death of Tilahun Gizaw, Sibhatu Wubneh and other, the hostility between Tegaru students and the government was intensified. It is stated that the cooperation and unity among Tegaru university students was further consolidated after the death of Tilahun Gizaw and the massacre of others. Tegaru students from different campuses (Sidist Kilo, Arat Kilo, etc) arranged frequent meetings and agreed on the need to establish an association of their own, under which they would create a united common front so as to struggle against the feudal rule. As a result, the Tigrean University Students Association (TUSA) came into being in the late 1970s (Mulugéta, 2010, p. 47). ${ }^{20}$

In August 1971, the involvement of Tegaru university students in Meqele was very active. Even though the situation in the town was very difficult for their political activities due to the close supervision of the security forces, they wasted no time to agitate mass based opposition against the feudal rule. Most of the time, their movement was without the knowledge of the state authorities in the town. For the sake of security, they prepared pamphlets written in Amharic and Tigrigna languages and posted them in every bar and commercial shops during the night time.

Their pamphlets had strong toned message including a picture of weapons painted using red ink. Most of the 
pamphlets post in such places were found and taken by the security forces that used such materials to tarnish the image of the university students among the government authorities in the town and the local community as well. They also used it to show the nature of the activities on which the university students were engaged in. ${ }^{21}$

Having such materials as evidences, the security forces began to chase the Tegaru university students in the town and the former tried to closely supervise the day-today activities of the latter. Not only the security forces used this pretext as a means to intimidate the university students but also they attempted to create anxiety among the parents of these students that parents had to take the responsibility of stopping the illegal activities of their children unless the consequence would be very severe. In other words, after they clearly knew the daily activities of the university students, the security forces began to exploit the situation in various ways for their own ends. On one hand, they assert that they had enough evidence on what the university students were doing during the day and night times in the town. On this ground, the students had to give up their illegal political activities unless they would be subjected to severe punishment. ${ }^{22}$

On the other hand, the security forces managed to develop a sort of distrust among the university students and the local community. They began to tarnish the image of the university students on the mind of the society. This was mostly in order to deprive the university students' popular acceptance for their revolutionary ideas among the society. Because, the relationship between the Tegaru university students and the local community was considered as a threat for the imperial government. To this end, what the security forces recommended the local community to do was to cautiously supervise the day-to day activities of the university students and to contribute their own share in suppressing the illegal political activities of the students instead of sharing their revolutionary ideas and becoming their patrons and ardent supporters. 23

However, such attempts of the security forces ended in vain. Because despite the several intimidations, the university students continued posting various pamphlets on the wall of different bars and shops. As a result, the security forces believed that frustrating the students and their parents proved inadequate measure of stopping the students' illegal political activities. They rather decided to use forceful action to suppress the students' political activities in the town. The university students were cautious enough to develop good friendship with the secondary school students in the town. They preferred to arrange different political meetings under the pretext of several reasons such as academic or developmental issues. ${ }^{24}$

Due to what was happening on 22 August 1971, some top officials of the police force including lieutenant Colonel Desalegn Tekle Micael and Moto Haleqa Zelalem
Wasihun managed to meet and discuss with some university students. Zer'u Gesese (later Agazi), who was by then second year university student and later one of the most influential founders of the Tigrean People Liberation Front /TPLF/, was consulted by the aforementioned personalities. What is interesting here to point out is that he never denied the university students' activities including posting pamphlets in the town. However, he was cautious for his nature of communication with these personalities.

As the police officials asked him to express his idea about the nature of the university students' involvement in the political opposition in Meqele against the imperial regime, his response to them was that the pamphlets, which were posted on the walls of bars and shops, were prepared by the university students. As to him, these pamphlets had no political content. Instead, the most important message of these materials was that the university and secondary school students want to develop common understanding regarding how to improve the teaching learning environment. This is to show that Zer'u Gesese tried his best to deceive the police forces that what the university students had written and posted in different places had apolitical message or nature. ${ }^{25}$

During the establishment of TUSA, Brhane lyasu, Aregawi Berhe, Equbazgi Beyene, Asfeha Hagos (Alemayehu), Wizerit Gidey Gebre Egziabher, Zer'u Gessesse, Alemayehu Wolde Aregai, Gebre Medhine Gebrekristos and others participated (Mulugéta, 2010, p. 49). ${ }^{26}$ TUSA pledged to function both in Addis Ababa and Tigray when the university was closed for the vacations. TUSA was a popular association in which many Tegaru university students, including all the founding members of the Tigrean Nations Organization (TNO), actively involved in the association's activities not only during the vacation times but also during the academic years. As members of the university community, members of TUSA were active participants at all levels of the pan-Ethiopian student movement. They managed to take a leading role in many cases of the ESM. For instance, Melese Tekle (who was later killed by the Derg) and Amha Tsehaye (today's Abay) were TUSA members who led the editorial branch of USUAA. The leadership of the Political Science Students' Association of HIU was put under Aregawi Berhe for a year (1972-1973). Brhane lyasu, before he joined the Ethiopian People's Revolutionary party (EPRP) and killed by the Derg, was a TUSA activist (Aregawi Berhe 2008, p. 59). ${ }^{27}$

In Addis Ababa, the main objective of TUSA was selecting some hot issues, arranging discussions and consulting some influential Tegaru, who were capable enough to back up the association. The members of TUSA managed to meet some parliamentarian, businessmen and professional Tegaru whose moral and material support was vital in order to mitigate the dismal situation in Tigray. Ato Gesesew Ayele (Sihul), Ato Asfaw Wolde 
Aregai, Ato Alemseged Gebre Egziabher, Weizero Tsehaytu Gebreslasie, Qegnazmach Teklit Mekonen, Ato Zenawi Tekola and others were among the members of the imperial parliament representing Tigray and contributed their immense share in terms of finance and advice. A considerable number of Tegaru intellectuals and professionals such as Ato Bekele Brhane, Doctor Asefa Abrha, Doctor Itbarek Gebre Egziabher, Ato Tsehaye Hailu, Ato Hagos Atsbha, Ato Kidane Asayehegn, Ato Aynalem Aregahegn and Doctor Tesfay Berhe, too, helped and encouraged TUSA in its struggle against the feudal regime (Mulugéta, 2010, p.59). ${ }^{28}$

TUSA played a pivotal role in shaping the political consciousness of secondary school students and government officials in and out of Tigray. Various cultural shows and sport matches were arranged which in turn helped many concerned Tegaru to meet together and to discuss their problems and the ways to address them. Under such meetings, the extent to which the people of Tigray was oppressed and exploited by their government appointed administrators was evinced in clear language. The organization of TUSA became strong and broadened since the 1972 and it encompassed political, economical, social and cultural issue (Hassiet, 2012). ${ }^{29}$

TUSA had two most important clandestine occasional papers: Etek (Be Armed) and Dimtsi Bihere Tigray (Voice of the Tigrean Nation) in which various political articles were produced and distributed among readers free of charge. The main contents of these occasional papers were agitation in nature and served as bridge linking Tegaru who were engaged in various walks of life and different corners of the country (Tsegu, p. 22). ${ }^{30}$

Different sources reveal, besides to its function in the capital, the major activities of TUSA were carried out in the eight awrajas of Tigray: Adwa, Aksum, Shire, Kilte Awla'elo, Enderta, Temben, Agame and Raya-Azebo. The members of TUSA performed their tasks when the university was closed for vacations (Aregawi, 2004, pp. 577). ${ }^{31}$

According to oral and written sources, the major focus of TUSA's activities in Tigray were abolishing illiteracy, reconstructing deteriorated old schools and health centers, delivering supplementary education for secondary school students who scored lower result or those who failed to pass exams, developing good cooperation with awraja municipal officers so as to initiate people to clean towns and to participate in aforestation and reforestation programs.

Besides, it involved in sharing revolutionary ideas of the Struggle Newspaper among people with whom they had contact, cautiously approaching some popular and prominent elders of each locality with whom they discussed the major problems of Tigray and their respective solution and raising the political consciousness of the secondary school students. Equally important, the association conducted research on some burning issues related to land tenure system, taxation system, the relationship between the Ethiopian Orthodox Church and the state in Tigray. It also identifies some other problems and suggested their possible solutions that could be achieved through determined struggle against the oppressive regime. Since 1970, members of TUSA began to go to Tigray during the vacations (Mulugéta, 2010, p. 50; Selemawit 2007). ${ }^{32}$

Educational (supplementary education) and developmental (forestation and cleaning) activities were carried out with legal permits and the co-operation of the governor of Tigray, Leul Ras Mengesha Seyum.

However, the association's political awareness creation program was performed without the knowledge of the provincial government authorities. TUSA effectively used every opportunity that would help it to disseminate its revolutionary ideas so as to raise the level of political consciousness of the people of Tigray as a whole. Leaflets, songs and informal discussions, which were carefully arranged, were used for the sake of disseminating revolutionary ideas among the masses.

The extent to which TUSA was careful for its discussion with the illiterate population of Tigray was that it made no mention of Marxist ideology but to the young educated revolutionaries. Its activities were most successful for the fact that in those days everyone seemed motivated to exchange revolutionary ideas advocating change. According to Aregawi, "The call for armed struggle to get rid of the oppressive feudal regime was entertained more often than it was mention." 33

However, TUSA did not perform its tasks without several impediments. Rather, there were various challenges that members of TUSA had to encounter. They were ordered to present periodic report to the police regarding the situation in their respective awrajas. Municipalities and secondary school personnel were warned not to cooperate with the members of TUSA instead to impose hurdles preventing TUSA from achieving its political missions. Those members of TUSA who managed to continue performing their activities despite of the deliberately imposed obstacles were under a state of close supervision of the security forces. Their parents were frequently summoned to police stations and ordered to stop the illegal activities of their sons unless the consequence of failing to do so would be severe at all (Mulugéta, 2010, p. 53). ${ }^{34}$

As stated before, the period 1972 was a crucial time in the Ethiopian Student Movement history. It was the time when there was horrible famine in Tigray and Wollo Provinces where many thousands of people lost their lives and their livestock as well. Students who were arrested following the death of Tilahun Gizaw were not released. It was also the time when six university students including Wallillegn Mekonen and Marta Mebrahtu were killed for their attempt to hijack Ethiopian aircraft. ${ }^{35}$

Security officials in Meqele Town were assigned to 
closely supervise the day-to-day activities of the member of TUSA. On 22 September 1972, Lieutenant Colonel Dessalegn Tekle Michael and Commandar of hundred Zelalem Wasihun met and asked one of the TUSA members, Zer'u Gessesse, who was a second year university student, about the illegal action of posting different political pamphlets. Zer'u replied that such pamphlets were posted by them, the members of TUSA, and he argued that the pamphlets had no political agenda. Rather, as to him, they were prepared and posted in the school compound of Atse Yohannis Secondary School to mobilize the students of the respective school to participate in the developmental activities of their school.

After this time, Tegaru university students began to meet frequently and decided to organize their association in a way that could pave the way to armed struggle. In 1973, as usual, Tegaru from different campuses of HIU held meeting and elected Seyum, who became member of TUSA immediately after its establishment, as the chief of the association. It was the time when many university students were arrested. "Land to the Tiller," "Respect democratic rights," "Education to sons of the poor" were common slogans of the time. The police used force to desperate student gatherings. Hailay Hadgu, in his book TSene'at, stated that Seyum Mesfine was recording the dismal in Arat Kilo, Sidist Kilo, Piazza and Churchill Street using camera. Since the situation in the university was uncertain, Seyum and other members of TUSA decided to leave Addis Ababa and to continue the struggle against the oppressive rule. Seyum Mesfine, Zer'u Gesese, Aregawi Berhe, Fantahun Zer'atsion and others met together to devise programs on how to run the

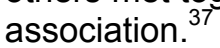

In the mid 1973, the government called university students to continue their university education. TUSA members left Tigray and returned to Addis Ababa, where they wasted no time to arrange meetings and to present papers dealing with land tenure, taxation in Tigray, the deliberate oppression of the people of the province and their migration to different direction of the country. Almost all papers presented called the need for encouraging the people of Tigray to be alarmed for struggle against the oppressive rule, which denied them their right to speak and write using their mother tongue language, Tigrigna, and violated their right to self-administration within the multi-national Ethiopia. ${ }^{38}$

Tegaru members of TUSA agreed to struggle against the old regime supporting the case of peasants, workers and government employees. The types and nature of songs that would be used by the people of Tigray to express their grievance on the feudal rule was discussed in detail. The need to have well-established political party to lead the people of Tigray's struggle was pronounced (Haila, 2010). ${ }^{39}$

During the vacation of 1973 , members of TUSA were given their assignments to perform in Tigray. Initially, they faced no/little challenge from the state authorities in the province. This is because, their hidden agenda was not explicitly known. This helped members of TUSA to disseminate their anti-feudal revolutionary ideas secretly but successfully. They taught the people how to overthrow the oppressive rule through armed struggle. ${ }^{40}$

In different awrajas of Tigray, different papers dealing with liberation movements and the role of unity to solve different social and political problems were presented. Invoking songs were sang by some very famous singers at local beer houses, marriage ceremonies, Ashenda (local ceremony held on mid August each year) and other occasions as to provoke the masses against the feudal regime. Songs revealing the oppressive nature of the old regime and the court corruption in Tigray were sung during various occasions (Mulugéta, 2010, p. 53). ${ }^{41}$ Particularly, during the $13^{\text {th }}$ month of Ethiopian calendar, pagumie, people sprang holy water and spent five to six days holding religious ceremonies chanting:

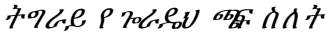

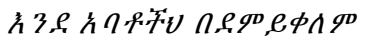

+ore hloth hno

H 3 ,éch ACT 4 D.h 7 lo:: (Haila, 2010). ${ }^{42}$

People of Tigray, shade the tip of your sword With blood as your forefathers

Tigray, and source of my proud and dignity My country, today is must [to fight against the regime]

In the mean time, several writings were dispatched in Tigray by the TUSA members. What is interesting here to note is that the extent to which the arrangement of sport matches in Tigray were effectively exploited by the TUSA members for their political ends. According to Mulugeta et al. the authors of Galahti Segi and Tsene'at respectively, sport matches were arranged in different awrajas of the province, where people got good opportunity to meet each other, to discuss about the dismal situation in Tigray and to exchange or distribute pamphlets among each other (Mulugéta, 2010, p. 53). ${ }^{43}$

After the end of the vacation of 1973, members of TUSA returned to Addis Ababa. However, due to very tense clash between the students and government security forces, the university was closed down. By that time, TUSA members wasted no time to call meeting to reach on a common agreement on how to continue their struggle against the feudal regime (Haila, 2010). ${ }^{44}$ The members of TUSA established a politically conscious group called Mahber Gesgesti Bihere Tigray (MAGEBT) at the beginning of 1974. MAGEBT means the Association of Progressives from the Tigray Nation and it was named Tigrean National Organization (TNO) for the sake of convenience. TNO was the mother organization of Tigray People's Liberation Front (TPLF). ${ }^{45}$ 
Since the mid 1974, many Tegaru out of the campus of Addis Ababa University were invited to be patrons of the planned armed struggle of the people of Tigray. They were made to contribute their share in the struggle. The creation of common understanding about the dismal condition in Tigray province was given due attention. TUSA firmly believed that public based organization was uncompromising precondition for the sake of materializing the objective of the struggle against the feudal rule of Emperor Haileslasie. Discussing about the challenges of the people of Tigray in particular and the people of Ethiopian in general became a burning issue of that time (Hassiet 2012, p. 40). ${ }^{46}$

In the mean time, other clandestine political groups began to appear in Tigray. "वqdnc. Thth +,כל"." (Political Association of Tigreans (PAT)) was good case in point.

This political group had strong urban network. It was under the leadership of Yohannis Teklehaimanot and Gebrekidan and later it was renamed as Tigray Liberation Front (TLF). TLF involved in a purely political mobilization of Tegaru against the old regime and it advocated the independence of Tigray (Aregawi, 2004, pp. 578-79). ${ }^{47}$ Hassiet Fiseha states, this group believed that "796.,

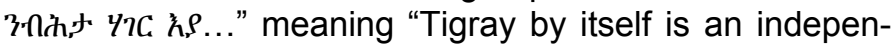
dent country." Due to its secessionist objective, he claims, TLF lost popular support among the politically conscious Tegaru (Hassiet 2012, p. 41) ${ }^{48}$

TNO came into being following the meeting held on 14 September, 1974. It was an association of progressive Tegaru intellectuals and students. It played a vital role in politicizing many Tegaru in the main towns. It called for political and economic change. It also made a decisive contribution to the popular uprising which was to topple Emperor Haileslasie from his power in Febuary 1974 (Jenney, 1989). ${ }^{49}$

Those members of TUSA who participated during the formation of TNO were seven in number. These include Zer'u Gessesse (Agazi), Fantahun Zer'atshion (Gidey), Mulugeta Hagos (Asfeha), Embaye Mesfine (Seyum), Alemseged Mengesha (Hailu), Amha Tsehaye (Abay) and Aregawi Berhe (Berihu) (Aregawi, 2004, pp. 57879). ${ }^{50}$ Zer'u, Fentahun, Mulugeta and Embaye, Alemseged, and Aregawi were the students of Law, Mechanical Engineering, Natural Science, Social Science and Political Science respectively. Abay was also a student of History and editor of Tagel (Hassiet 2012, p. $45) .{ }^{51}$

The founders of TNO met at a café in piazza, in the center of Addis Ababa. Even though he did not attend the meeting for security purpose, Gesesew Ayele (Sihul), who was a parliamentarian for two terms and highly respected representative of Tegaru at the time, was member of the founding comrades (Aregawi, 2004, pp. 578-79). ${ }^{52}$

It is necessary to note here that the aforementioned Tegaru were not the only conscious and committed during the formation of MAGEBT. Rather many Tegaru university students played a prominent role. If so, why did the number of founding fathers of MAGEBT remain seven? This is a key question that needs to be answered here. The reason why the founders were kept numerically few was for security purpose. Unless the founding members kept small in number, their objective of meeting together would reach the ears of the then government officials and this would lead to costly loss (Hassiet 2012, p. 45$)^{53}$

According to an interview made at February 2009 by a Weyeen Magazine with Ato Arkebe Equbay, who was one of the Tegaru university students during the early 1970s, the movement of young intellectuals was influenced by several factors. First, the armed struggle that was already begun in Eritrea had great impact on the political consciousness of the university students of Ethiopia in general and Tigray in particular.

Second, the liberation struggle of Vietnam, Kuba and other countries provided the Ethiopian intellectuals and students with a good lesson that armed struggle was a mandatory to topple a feudal and oppressive regime. The educated men of Ethiopia managed to acquire an impressive experience of liberation struggles of different countries through reading many books and articles. As they read more about the issue mentioned above, their need to a change in government increased. Next, their age level had its own impact on the nature of students' movement during the imperial regime. It is clear that most of the university students were between 18 and 21 years old. Their maturity highly shaped their reactionary movements. ${ }^{54}$

There was political radicalism among the young educated generation dedicated to fight against imperialism and feudalism; system that were believed to have kept Ethiopia in the most backward stage of development. The educated classes were revolutionaries demanding the end of Ethiopian backwardness through revolution. They were busy reading different books which helped them to be familiar with the experiences of the Bolshevik of Russia, Maoism of China, Hoche Minh of Vietnam and Che Guevara of internationalism. The revolutionary students were ready to pay any sacrifice to topple the old regime in Ethiopia, which was considered, by them, as the "prison house of nationalities (Aregawi, 2004, p. 581)."

According to Aregawi, several factors contributed for the development and intensification of Ethno-nationalist sentiment among the young educated class. The power monopoly of the dominant Shoan Amhara feudal class was among the prime factors leading to ethnic resistance. The influence of peasant rebellions in Tigray (Woyane Rebellion of 1942-43, Gojjam (1967); Bale (1963-68) and the armed struggle in Eritrea (1960s-1970s) served as a historical precedents to challenge the existing oppressive state of affairs. Equally important, the harsh punitive 
(retaliate) measures undertook by the government as a means to suppress such sentiments were not forgotten by those who were victims of those measures (Aregawi, 2004, p. 581-82).$^{56}$ For instance, the bombardment of innocent people of Tigray in Meqelle during the 1942/43 by the British Royal Aircraft was not erased from the mind of Tegaru. ${ }^{57}$

The central government, as stated before, forbade the people of Tigray to speak Tigrigna and to use it in schools, law courts and other institutions since the 1940s. The people were forced to live far below subsistence due to higher degree of land degradation. What was horrible is that not only government authorities neglected the plight of the people of Tigray but also levied different forms and amounts of taxes that was beyond the capacity of peasants to pay it. As a result, very large number of peasants left their villages with or without their families and migrated to distant areas in search of job. It was not uncommon to see desperate families seeking shelter in churches and mosques and begging for food in the streets (Brhanu, 2011). ${ }^{58}$

This situation became a fertile ground to the persistent call of the young educated class for radical change to be popularly accepted among the masses. Cultural domination, heavily taxation and the state's reluctance to give timely solution to serious problems were sources of complaints among the people of Tigray. As quoted in Aregawi's article, it is stated that, "The most painful cut of all was the banning of the Tigrai language in a region where, as late as the mid 1970 s, only $12.3 \%$ of the males claimed to speak Amharigna and only $7.7 \%$ could read it (Aregawi, 2004, p. 583).."

After several meetings were arranged by the TUSA members at the beginning of 1974, Tegaru university students agreed to go to Tigray and to alarm the people of Tigray for armed struggle against the feudal regime. This commitment was not performed without any obstacle. Financial problem was the most acute. After their agreement to go to their respective awrajas, some members of the association faced financial constraint to cover their travel expense. But, they wasted no time to solve the problem, at least for a while. Seyum Mesfine and Fantahun Zeratsion, representatives of Tegaru students of Arat Kilo, and Sidist Kilo respectively solved the problem by covering the travel expense of those who had no money for such purpose from the money that was collected from the members of TUSA. In the mean time, Seyum Mesfine and some of his friends stayed in Addis Ababa for some times for the sake of developing programs and directions of their struggle against the Ethiopian Government (Haila, 2010).. ${ }^{60}$ The number of Tegaru university students who actively participated in inciting revolution among the people of their respective awrajas in the 1970s was believed to be large in size (Mulugéta, 2010, p. 50-1). ${ }^{61}$

The above mentioned and other Tegaru university students were so eager to prompt the outbreak of popular revolution supported by the people of Tigray against the old regime. They managed to win the support of considerable number of government employees and the masses as a whole to whom the objectives of the former were told and accepted with no tendency to hesitate. For the sake of disseminating their revolutionary ideas against the feudal regime, the Tegaru university students arranged theaters, prepared songs and poems that could show the oppressive nature of the old regime (Haila, 2010).. ${ }^{62}$

As stated before, Seyum and some other Tegaru university students waited in Addis Ababa for some times while many of their friends already went to Tigray. After they had finished devising directions of the struggle against the regime, they followed the footsteps of their friends and marched to Tigray, their beloved province for which they paid a lot of sacrifice for the betterment of their community. When they arrived at Meqele, Seyum managed to meet Agazi and Rezene with whom he discussed the direction of the struggle after which he went to Adigrat. In Adigrat, Seyum met some Tegaru university students including Brhane lyasu and Tewelde Gebreegziabher and used to work with them for some times. He also visited his friends working in different parts of Tigray including in Adwa, Temben, Shire and Maichew. For instance, he consulted Solomon Tesfay, Aregawi Berhe, Alemseged Mengesha and Abay Tsehaye in Maichew, Adwa, Temben and Aksum respectively. He also met Fantahun Zeritsion and Mulu Hagos in Shire (Aregawi, 2004, p. 583). ${ }^{63}$

The Tegaru university students were mostly active in towns and in rural areas to some extent. In the rural areas, during different occasions, while farming and celebrating religious holydays or attending weeding ceremonies, people of Tigray frequently sang songs alarming the masses for an alarmed struggle against the repressive system to the end. Among the uneducated people of Tigray, ideas were expressed orally and well expressed through song more than through other means. The following were two of the most popular songs that clearly reflected the anger of the people.

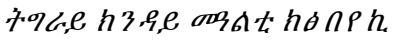

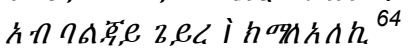

Tigray, how long should I linger?

Let me get it [the gun] for you

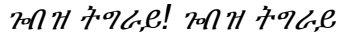

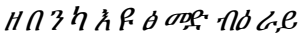

Brave of Tigray! Brave of Tigray

Now is your time to mount the ox [weapon]. (Aregawi, 2004, p. 583)

The people of Tigray evinced their hardships in different ways. For instance, the absence of effective and 
responsible administrator in the province was expressed

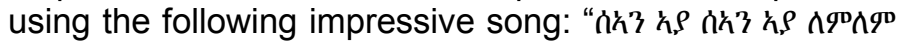

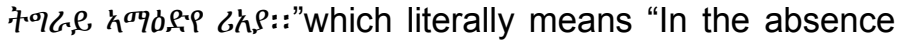
of good governor (father), I saw Tigray from a distance (Hassiet 2012, p. 41)." 66

TUSA successfully mobilized the people of Tigray in particular and the peoples of Ethiopia in general. It won the support of masses population. The people of Tigray were ready to pay any form of sacrifice for the sake of liberating themselves from the oppressive rule of the imperial government. Their readiness for armed struggle against the old regime was expressed using the following song:

\section{+quge q,e

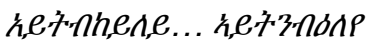

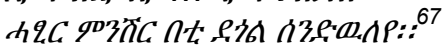 \\ Tigray, my homeland \\ Do not cry, stop weeping \\ Equip me with small minishir (weapon)}

TUSA began to consolidate its power and increase the number of its supporters. It created conducive environment for armed struggle. The members of this association were closely observing the situation in the country. As stated above, some influential Tegaru including Gidey Gebre Egziabher, Seyum Mesfin, Aregawi Berhe, Equbazgi Beyene and others took the leadership of the association. In the mean time, the people of Tigray were ready for armed struggle against the oppressive imperial rule. They were waiting an appropriate time and condition. They frequently pronounced several songs including:

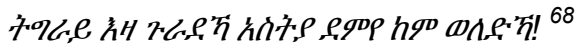 \\ Tigray, add your sword into blood as your forefathers

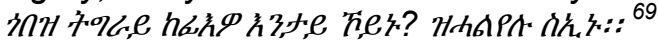 \\ Brave Tigray is disappointed why? \\ Due to the absence of responsible body
}

The movement of Tegaru educated men under TUSA (later MAGEBT and then TPLF) was not only confined to liberate the people of Tigray from oppressive old regime under the leadership of Emperor Haileslasie and his companion. Rather their struggle had long run goal: ensuring economic, social, political and cultural freedom of the people of Tigray in particular and the people of Ethiopia in general even after the fall of the old regime. After the coming of Derg to power, the struggle in Tigray was highly intensified. A change in government did not bring anything good for the people of Tigray but by far brutal and blood thirsty government.

In the mean time, the people of the province hand no chance than continuing to pay their golden life, time and property for the sake of restoring bright future for their off springs. Thanks to educated Tegaru, MAGEBT distributed different leaflets exposing the brutal nature of the Derg regime at an alarming rate. Some of the leaflets were

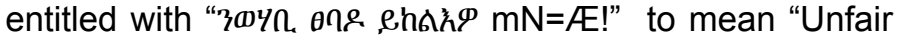
advantage" and "T. "One parasite leaves out and another dangerous parasite flees in."70

\section{Conclusion}

During the Italian occupation of Ethiopia between 1935 and 1941, the people of Tigray paid costly sacrifice to liberate their country. However, the fight of Emperor Haileslasie to Britain highly wounded their moral. For this reason, his centralization policy of the early 1940s lacked acceptance among the people of the province. They believed that they were culturally alienated and politically suppressed. Three years after the expulsion of the Italians from the county, First Woyane Rebellion broke out in Tigray that put the emperor's stay in power under question. Even though he managed to suppress it using the British Royal Airplanes, the people of the province did not remain submissive to the imperial regime.

Nevertheless, until the 1960s, the form of opposition in the province had no overt nature. It was in the 1960s that Tegaru intellectuals began to play a pivotal role in agitating mass-based political opposition in the respective province. Especially those who joined Haileslasie I University from different awrajas of Tigray established very strong unity and became major actors of that time. Under their umbrella association, TUSA, they effectively exploited every opportunity to dispatch revolutionary ideas among their society. They prepared several political pamphlets and dispatched them among several secondary and elementary school students.

They met secondary school students in two ways. First, some Tegaru university students went to their respective awraja during the vacation time. Second, some other visited their awrajas for one year national service purpose. During both occasions, they were not free to perform their political activities. However, despite the very tight supervision by several security forces, they did their best to alarm the mass for armed struggle. Not only they took lion's share for the downfall of the imperial regime in 1974 but also they laid ground for the bitter but successful guerrilla fighting against the Derg Regime.

Even though the political movement of Tegaru University students during the imperial regime attracted the attention of some scholars, no adequate literature is produced on it. Because, some written sources provides us with very simple highlights with no sufficient explanation and discussion. Some authors also used very limited sources to deal with the issue under discussion. However, this paper tries its best to address such lacuna. It attempts to provide readers with deep analysis and explanation about the shift from peasant to intellectualsled political movement against the imperial regime. 
Equally important, this paper is produced based on rich historical sources. Many primary and primary sources are used to conduct this research.

\section{Conflict of Interests}

The author has not declared any conflict of interests.

\section{REFERENCES}

Aregawi B (2004). "The Origins of the Tigray People'sLiberation Front," African Affairs 103(413):569-592. http://afraf.oxfordjournals.org/content/103/413/569.abstract?ck=nck

Aregawi B (2008). A Political History of the Tigray People's Liberation Front (1975-1991): Revolt, Ideology and Mobilization in Ethiopia. Amsterdam:Verije University. http://www.amazon.com/PoliticalHistory-Peoples-Liberation-1975-1991/dp/1599070413

Atsbha Gebre Egziabher (2012). Change and Continuity in the Ethiopian Sub-Provinces: A History of Endärta Awraja (1941-1974). Saabrucken, Lambert Academic Publishing. http://biblio.co.uk/book/change-continuity-ethiopian-provinces-historyendarta/d/615391701

Jenney H (1989). Kab Mear Ziti'em Sweeter than Honey: Testimonies of the Tigrean Women. (London: Links Publication).

Young J (1998). "The Tigray People's Liberation Front." In African Guerrillas (eds.) Christopher Clapham and James Currey.

Selemawit G (2007). "Life in $20^{\text {th }}$ Century Ethiopia: An Autobiographical Narrative of Foreign Minister Ato Seyum Mesfine, "BA Thesis in History and Heritage Management. Addis Ababa: Addis Ababa University.

Tsegu Gebre Yesus. 2009. "National Oppresion and National Liberation Struggle: The Case of Birth of TPLF," BA Thesis in Political Science and International Relations. Addis Ababa: Addis Ababa University.

\section{Citations}

${ }^{1}$ Informants: Memhir Weldegebriel Tadese; Memhir Gidey, Memhir

Brhane Tsegay, Memhir Aregawi G/Mariam, Memhir Atsbha Asegedom

${ }^{2}$ Atsbha Gebreigziabher, Change and Continuity in the Ethiopian SubProvinces: A History of Endärta Awraja (1941-1974). Saabrucken, Lambert Academic Publishing, (2012),pp.39-40.

${ }^{3}$ Infromants: Memhir Weldegebriel Tadese; Memhir Gidey, Memhir Brhane Tsegay, Memhir Aregawi G/Mariam, Memhir Atsbha Asegedom

${ }^{4}$ Informant: Dr Solomon Inquai; Weyeen Magazine, No.33, Ginbot, 2002 E.C.

${ }^{5}$ Informant: Memhir Mamo Tekle Haimanot, Dr Solomon Inquai; Weyeen Magazine, No.33, Ginbot, 2002 E.C.

${ }^{6}$ Informant: Memhir Mamo Tekele Haimanot

${ }^{7}$ Informant: Dr Solomon Inquai; Weyeen Magazine, No.33, Ginbot, 2002 E.C.

${ }^{8}$ Ibid.

9 Informants: Memhir Weldegebriel Tadese; Memhir Gidey, Memhir Brhane Tsegay, Memhir Aregawi G/Mariam, Memhir Atsbha Asegedom ; Aregawi Berhe, "The Origins of the Tigray People'sLiberation Front," African Affairs (2004), 103/413, p.576.

${ }^{10}$ Aregawi Berhe, A Political History of the Tigray People's Liberation Front (1975-1991): Revolt, Ideology and Mobilisation in Ethiopia. (Amsterdam:Verije University,2008), p.59.

${ }^{11}$ Aregawi Berhe, "The Origin...", p.576.

12 John Young, "The Tigray People's Liberation Front" in African Guerrillas (eds.) Christopher Clapham and James Currey.(1998), p.37.

${ }^{13}$ Weyeen Magazine, Hizbawi Qalsi Hiwehat (1967-1992) prepared for the $25^{\text {th }}$ Year ancillary of TPLF, page 8; Hiwehat: Democracyna Democraciyawi Andinet Be Ethiopia, page 14-15); Informants: Memhir Weldegebriel Tadese; Memhir Gidey, Memhir Brhane Tsegay, Memhir Aregawi G/Mariam, Memhir Atsbha Asegedom.

${ }^{14}$ Aregawi Berhe, A Political History..., p.59.

${ }^{15}$ Weyeen Magazine, No.28, pp.18-19.

16 Informants: Dr Solomon Inquai, Ato Goitom Tadese, Memhir Woldegebriel Tadese; Mulugéta Debalkew. Galahti Seggi: Ye Hwehat Ye Tiţiq Tigil Tarik (1967-1983 E.C.). (Addis Ababa: np 2002 E.C.), p.47.; Aregawi Berhe, A Political..., p.59.; Aregawi Berhe, "The Origin...," p.576.; Weyeen Magazine, No.30 .

${ }^{17}$ Archive (Tir 27/1962 E.C); Weyeen Magazine, No.30

${ }^{18}$ Ibid.

${ }^{19}$ Mulugeta Debalkew, p.47.

${ }^{20}$ Mulugeta Debalkew, p.47.; Aregawi Berhe, A Political..., p.59.; Aregawi Berhe, "The Origin...," p.575.

${ }^{21}$ National Archive and Library Agency Archives (N.A.L.A.A) Box No. 297/4, File No 227. From Legese Bezu to Administrative Office of Tigray Province. September 12, 1973.

${ }^{22}$ N.A.L.A.A. Box No. 297/4, File No. 71/25/17347. From Debebe Hursa to the Imperial Government Ministry of Interior. August 28, 1973.

${ }^{23}$ Ibid.

${ }^{24}$ N.A.L.A.A. Box No. 297/4, File No. 5566. From Tegaru university students to Atse Yohannis Secondary School students. August 22 1971

${ }^{25}$ N.A.L.A.A. Box No. 297/4, File No. 23/144/24/4. From Colonel Brhanu to Dejazmach Zinahbuzu Mesay, Deputy governor general of Tigray province. October 1. 1972

${ }^{26}$ Mulugeta Debalkew, p.49.; Memhir Weldegebriel Tadese; Memhir Gidey, Memhir Brhane Tsegay, Memhir Aregawi G/Mariam, Memhir Atsbha Asegedom.

27 Informants: Dr Solomon Inquai, Ato Goitom Tadese, Memhir Woldegebriel Tadese ; Aregawi Berhe, "The Origin...," p.577.; Tsegu G/Yesus, "National Oppresion and National Liberation Struggle: The Case of Birth of TPLF," BA Thesis in Political Science and International Relations. (Addis Ababa: Addis Ababa University, 2009), p.22.

${ }^{28}$ Mulugeta Debalkew, p.51.; Aregawi Berhe, A Political..., p.59.; Aregawi Berhe, "The Origin...," p.577.; Informants: Memhir Brhane Tsegay, Memhir Amauel Teklu, Memhir Fiseha Tesfay; Memhir Atsbha Woldemikael.

${ }^{29}$ Hassiet Fiseha, Qiya Tegadilo: Tarik Qalsi Hiwehatin Hizbi Tigrayin (1967-1993) (2004 E.C), p.40.

30 Mulugeta Debalkew, p.53.; Aregawi Berhe, A Political..., p.59.; Aregawi Berhe, "The Origin...," p.577.; Tsegu G/Yesus, p.22.

${ }^{31}$ Aregawi Berhe, "The Origin...," p.577. Informants: Dr Solomon Inquai, Ato Goitom Tadese, Memhir Woldegebriel Tadese.

${ }^{32}$ Mulugeta Debalkew, p.50.; Hassiet Fiseha, p.39.; Selemawit Gidey, "Life in $20^{\text {th }}$ Century Ethiopia: An Autobiographical Narrative of Foreign Minister Ato Seyum Mesfine, "BA Thesis in History and Heritage Management. (Addis Ababa: Addis Ababa University, 2007), p.6.; Informants: Memhir Brhane Tsegay, Memhir Amauel Teklu, Memhir Fiseha Tesfay; Memhir Atsbha Woldemikael.

${ }^{33}$ Aregawi Berhe, pp.577-578.

${ }^{34}$ Mulugeta Debalkew, p.53.; Informants: Memhir Brhane Tsegay, Memhir Amauel Teklu, Memhir Fiseha Tesfay; Memhir Atsbha Woldemikael.

${ }^{35}$ Ibid.

${ }^{36}$ N.A.L.A.A. Box No. $297 / 4$, File No. 23/144/24/4. From Colonel Brhanu to Dejazmach Zinahbuzu Mesay, Deputy governor general of Tigray province. October 1. 1972.

${ }^{37}$ Hailay Hadgu. Tsin'at: Ewneteňa Tarik. (Mäqällä: np, 2002 E.C), p.12.

${ }^{38}$ Informants: Informants: Memhir Weldegebriel Tadese; Memhir Gidey, Memhir Brhane Tsegay, Memhir Aregawi G/Mariam, Memhir Atsbha Asegedom; Ato Goitom Tadese; Hailay Haddgu, p.14.

${ }^{39}$ Hailay Haddgu, p.15.

${ }^{40} \mathrm{Ibid}, \mathrm{p} .13$.

${ }^{41}$ Mulugeta Debalkew, p.53.; Hailay Hadgu, p.15.

${ }^{42}$ Hailay Hadgu, p.15.

${ }^{43}$ Mulugeta Debalkew, p.53.; Hailay Hadgu, p.15. 
${ }^{44}$ Hailay Hadgu, p.13.

${ }^{45}$ Aregawi Berhe, "The Origin...", p.578.

${ }^{46}$ Hassiet Fiseha, p.40.

${ }^{47}$ Aregawi Berhe, "The Origin...", pp.578-579.; Hailay Hadgu, p.15.

${ }^{48}$ Hassiet Fiseha, p.41.

49 Jenney Hammond, Kab Mear Ziti'em Sweeter than Honey: Testimonies of the Tigrean Women. (London: Links Publication, 1989), p.19

50 Aregawi Berhe, "The Origin...," p.578-579.; Hassiet Fiseha, p.45.; Tsegu G/Yesus, p.22.

${ }^{51}$ Hassiet Fiseha, p.45.

${ }^{52}$ Aregawi Berhe, "The Origin...," pp.578-579.; Hailay Hadgu, p.15.

${ }^{53}$ Hassiet Fiseha, p.45.; Weyeen Magazin, No. 28, pp.18-19.; Hailay Hadgu, p.16.

${ }^{54}$ Woyeen Magazin No. 28, p.4.

${ }^{55}$ Aregawi Berhe, "The Origin...", p.581.

${ }^{56}$ Aregawi Berhe, "The Origin...., pp.581-582.

${ }^{57}$ Informants: Memhir Weldegebriel Tadese; Memhir Gidey, Memhir Brhane Tsegay, Memhir Aregawi G/Mariam, Memhir Atsbha Asegedom; Haji Tuha Siraj; Memhir Amanuel Teklu; Memhir Mamo Tekle Haimanot

${ }^{58}$ Ibid.

${ }^{59}$ Aregawi Berhe, "The Origin...," p. 583.

${ }^{60}$ Hailay Hadgu, p.13.

${ }^{61}$ Mulugeta Debalkew, pp.50-51.

${ }^{62}$ Hailay Hadgu, pp.13-14.

${ }^{63} \mathrm{Ibid}$.

${ }^{64}$ Aregawi Berhe, "The Origin...", p.583.; Hassiet Fiseha, p.41.

${ }^{65}$ Aregawi Berhe, "The Origin...," p.583.

${ }^{66}$ Hassiet Fiseha, p.41.

${ }^{67}$ Informants: Memhir Weldegebriel Tadese; Memhir Gidey, Memhir Brhane Tsegay, Memhir Aregawi G/Mariam, Memhir Atsbha Asegedom Hassiet Fiseha, p.43.

\section{Magazines}

Weyeen Magazin, No. 28, February 2009.

Weyeen Magazine, "Hizbawi Qalsi Hiwehat (1967-1992) prepared for the $25^{\text {th }}$ Year ancillary of TPLF." 2010.

Weyeen Magazine, No.30. November 2009.

Weyeen Magazine, No.33, Ginbot, 2010.

${ }^{68}$ Brhanu Abadi et al, Zanta Tegadilo, (2003 E.C.), PP.324-325.

${ }^{69} \mathrm{Ibid}$.

${ }^{70}$ Selemawit Gidey, p.7.

\section{Archives}

National Archive and Library Agency Archives (N.A.L.A.A)

Box No. 297/4, File No. 227

Box No. 297/4, File No. 71/25/17347

Box No. 297/4, File No. 5566

Box No. 297/4, File No. 23/144/24/4

\section{Informants}

Teacher Weldegebriel Tadese, interviewed on 10 September 2013, at Mekele Town Teacher Gidey G/Mikael, interviewed on 9 September 2013, at Mekele Town

Teacher Brhane Tsegay, interviewed on 14 August 2013, at Mekele Town

Teacher Aregawi G/Mariam, interviewed on 9 September 2013, at Mekele Town

Teacher Atsbha Asegedom, interviewed on 10 September, at Adigrat Town

Teacher Amanuel Teklu, interviewed on 8 September 2013, at Mekele Town

Teacher Mamo Tekle Haimanot, interviewed on 23 August 2013, at Mekele Town

Teacher Goitom Tadese, interviewed on 13 August 2013, at Mekele Town

Teacher Tuha Siraj, interviewed on 20 August 2013, at Mekele Town. 